
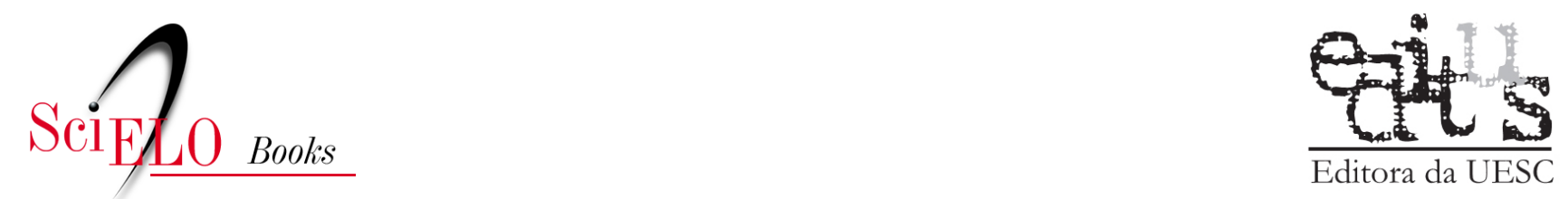

$\overline{\text { Editora da UESC }}$

\title{
Capítulo IV - Os fluxos de encontros na fronteira oitocentista em Cachoeira de Itabuna
}

\author{
Ayalla Oliveira Silva
}

\section{SciELO Books / SciELO Livros / SciELO Libros}

SILVA, A.O. Os fluxos de encontros na fronteira oitocentista em Cachoeira de Itabuna. In: Ordem imperial e aldeamento indígena: Camacãns, Gueréns e Pataxós do Sul da Bahia [online]. Ilhéus: Editus, 2018, pp. 204-258. ISBN: 978-85-7455-528-7. https://doi.org/10.7476/9788574555287.0005.

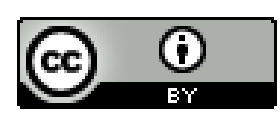

All the contents of this work, except where otherwise noted, is licensed under a Creative Commons Attribution $\underline{4.0 \text { International license. }}$

Todo o conteúdo deste trabalho, exceto quando houver ressalva, é publicado sob a licença Creative Commons Atribição 4.0. 


\section{CAPÍTULO IV}




\section{OS FLUXOS DE ENCONTROS NA FRONTEIRA OITOCENTISTA EM CACHOEIRA DE ITABUNA}

Neste capítulo, o objetivo central é analisar as relações estabelecidas entre os diferentes atores no processo da colonização oitocentista em Ferradas e Cachoeira de Itabuna. Esse interesse tem a ver com a inquietação acerca de considerar como agiam aqueles sujeitos históricos e com a preocupação em não construir uma narrativa na qual os índios de Ferradas apareçam apenas como força de trabalho explorada. Temos clareza de que sua atuação como mão de obra diz muito da trajetória histórica deles. Mas considerá-los, apenas, como força de trabalho traz a incômoda sensação de que sua atuação é somente determinada pelos interesses do colonizador e que eles não vislumbravam interesses próprios. Em poucas palavras, neste capítulo nosso interesse é desconstruir a imagem de que os índios eram passivos trabalhadores do governo imperial.

Em Ferradas, tanto os Camacans e Guerens aldeados quanto os Camacans, Botocudos e Pataxós não aldeados, habitantes da região, participaram do processo da colonização de forma dinâmica. A ideia é apresentá-los e evidenciá-los se transformando na história da colonização sul baiana, durante o XIX. O processo deve ser observado enquanto uma teia, um emaranhado de conflitos e negociações, resultantes do encontro dos diferentes atores e grupos sociais naquela parte do sul da Bahia. 
Nesse sentido, são direcionadoras para o nosso trabalho as reflexões de John Monteiro e Celestino de Almeida, pois ambos os autores fazem uma leitura etno-histórica da realidade social, em que os índios em situação de contato são vistos construindo e reelaborando suas identidades.

Monteiro critica a "crônica da destruição dos índios", presente na historiografia. Ele toma como exemplo as reflexões de Florestan Fernandes, para quem os Tupinambás, em Pernambuco, teriam mantido sua coesão tribal através da migração, pois a prática migratória os livraria do impacto da colonização ${ }^{1}$. John Monteiro salienta, contudo, a emergência de outras leituras possíveis para pensar a atuação indígena no mundo colonial. Para Monteiro, o viés da etno-história permite interpretações nas quais o impacto colonial "não se resume apenas na dizimação de populações e na destruição de sociedades indígenas" ${ }^{2}$. Ao contrário disso, as novas leituras da relação entre populações indígenas e o mundo da colonização fazem emergir "diferentes formas de sociedades nativas após o contato ou a conquista". ${ }^{3}$

Nos processos de etnogênese - entendido como "as novas configurações étnicas e sociopolíticas" emergidas na situação do contato - se dá a possibilidade de construção de uma nova chave de compreensão das relações interétnicas, que envolve a "colaboração" e a negociação entre os atores no mundo da colonização. Como bem observa John Monteiro, para aquela realidade, "O envolvimento em guerras coloniais, em rivalidades intraeuropeias ou no crescente tráfico de cativos indígenas mostrou-se uma importante estratégia para vários grupos que buscaram res-

\footnotetext{
1 MONTEIRO, John Manuel. Op., cit., 2001, p. 55.

2 Idem, ibidem.

3 Idem, p. 62.
} 
guardar a sua autonomia, paradoxalmente através desta 'colaboração'"4.

O movimento de ressocialização das populações indígenas nas aldeias coloniais do Rio de Janeiro, estudado por Maria Regina Celestino de Almeida, exemplifica muito bem os resultados de uma historiografia envolvida em analisar os índios se transformando na história do pós-contato. Nos termos da autora, se metamorfoseando. Almeida ressalta que o ingresso nos aldeamentos coloniais impunha aos índios um processo de perdas e mudanças, que dizia respeito, entre outros aspectos, à terra, ao trabalho e às práticas culturais. Contudo, através da leitura etno-política, a autora concebe a atuação política dos índios das aldeias coloniais e os percebe reelaborando e construindo suas identidades. Nesse processo, a ideia de cultura não passa por algo dado a priori ou essencial. Ao contrário disso,

Tal processo, entendido à luz da noção de cultura dinâmica e histórica articulada com várias evidências empíricas, revela toda sua complexidade, permitindo perceber as mudanças não só como simples perdas culturais, mas também como propulsoras das novas possibilidades de os índios se adaptarem à colônia ${ }^{5}$.

As informações concernentes à documentação capuchinha produzida durante a atuação dos frades administradores dos aldeamentos do sul da Bahia são, em sua grande maioria, pouco elucidativas acerca dos vários aspectos abordados neste estudo, entre os quais o trabalho

4 MONTEIRO, John Manuel. Op., cit., 2001, p. 63.

5 ALMEIDA, Maria Regina Celestino de. Op., cit., 2013, p.147. 
indígena e as relações interétnicas. Contudo, a partir de uma leitura realizada a contrapelo dessa documentação, pudemos demonstrar a relação entre os índios de Ferradas e os produtores de cacau. Com a mesma metodologia de análise da documentação, pretendemos demonstrar, conforme a documentação nos permita, as relações étnicas estabelecidas intra e extra-aldeamento de Ferradas; e analisar e entender os processos de conflito, negociação e ressocialização dos índios aldeados e não aldeados daquela parte do sul da Bahia.

\subsection{Agenciamentos indígenas em Cachoeira de Itabuna: conflitos e negociações entre autoridades governa- mentais, religiosas, índios aldeados e não aldeados}

Pensar as reelaborações das identidades das populações indígenas como possibilidade de constituição étnica tem agenciado importantes reflexões no campo da história e da antropologia. Como parte dessas reflexões, Guillaume Boccara destaca o protagonismo dos Mapuches no processo de colonização chilena. $\mathrm{O}$ autor propõe pensar os efeitos do poder e dos mecanismos colonizadores sobre as populações indígenas e como estas reconfiguraram-se social e politicamente no "espaço fronteiriço"6. Boccara identifica, no processo de contato, a recriação identitária mapuche, ao longo dos séculos coloniais, pois estes se apropriaram de elementos oriundos da colonização e frequentemente recriaram suas identidades em novas formas de organização política, econômica e social. $\mathrm{O}$ autor supera a ideia

6 BOCCARA, Guillaume. "Poder colonial e etnicidade no Chile: territorialização e reestruturação entre os Mapuche da época colonial". Tempo: UFF, v. 12 , n. 23,2007 , p. 60. 
de duas alternativas únicas e dicotômicas para pensar a atuação mapuche no Chile colonial: a de povo guerreiro e irredutível opositor do poder colonial; ou a ideia de povos indígenas em vias de assimilação. Boccara observa a realidade do contato enquanto espaço de atuação e negociação entre "colonizadores" e "colonizados". Nas palavras do autor: "a identidade étnica mapuche emerge tanto como um produto da confrontação bélica, como da negociação política com os wingka, os não-mapuche" ${ }^{\prime 7}$.

A perspectiva etno-histórica apresentada por Almeida e Monteiro, de uma (re) criação identitária dos índios na realidade do contato colonial, bem como o caso dos mapuches, estudado por Boccara, nos impulsionam e possibilitam observar a documentação sobre o sul da Bahia de uma forma mais complexa. Desse ponto de vista, os aldeados de Ferradas são vistos agindo conflitivamente sobre os não aldeados no esforço de garantir a integridade do seu lugar de sobrevivência no mundo colonial; ao passo que aqueles não aldeados se utilizam das estratégias possíveis, e muitas vezes resistem e lutam fisicamente para garantir seus interesses, principalmente a permanência e sobrevivência em seus territórios. Mas como veremos adiante, esses mesmos índios "hostis", que em dados momentos tentavam barrar, em alguma medida, o avanço da colonização em Ferradas e Cachoeira de Itabuna, em outros estabeleciam práticas de negociação com os administradores imperiais.

Para os índios em situação de contato, mas não aldeados, hostilizar o espaço do aldeamento, situação que tentaremos demonstrar nos parágrafos seguintes, significava atingir e abalar, de alguma forma, as práticas do indigenismo naquela região. No entanto, nem

7 BOCCARA, Guillaume. Op., cit., p. 71. 
sempre o agenciamento indígena se dava pela estratégia da guerra nas relações entre não aldeados e colonizadores. Na região de Cachoeira de Itabuna e Ferradas, no processo da colonização, a estratégia da guerra foi tão utilizada quanto a estratégia da negociação entre os índios e o governo imperial da Província da Bahia, como demonstram, subsequentemente, alguns casos que analisaremos.

Ao longo de todo o século XIX, segundo a documentação analisada, os Pataxós e Potocudos figuraram como entrave ao projeto colonizador nos discursos gestados pelas autoridades governamentais e religiosas. Dentre as principais queixas dos capuchinhos e das autoridades governamentais locais, estão as que fazem referência aos ataques daquelas populações ao aldeamento São Pedro de Alcântara, aos aldeados, à estrada e aos fazendeiros locais, com uma maior predominância dos ataques sobre os índios aldeados em Ferradas.

TABELA 4 - Principais tipos de queixas acerca da ação dos índios não aldeados

\begin{tabular}{|l|l|}
\hline Descrição da ação desenvolvida & Ocorrências \\
\hline Ataques às roças e fazendas & 3 \\
\hline Ataques na estrada & 2 \\
\hline Ataques às plantações do aldeamento & 5 \\
\hline Roubo de ferramentas & 3 \\
\hline Ataques à povoação aldeada & 8 \\
\hline Total & 21 \\
\hline
\end{tabular}

Fonte: Tabela construída a partir das correspondências trocadas entre autoridades locais e provinciais, entre os anos 1840-1859: APEB; maços: 4612, 4613 e 2395-I; Arquivo Colonial e Provincial.

Nessa direção, são elucidativas da atuação dos índios não submetidos ao processo de territorialização, algumas correspondências trocadas entre as autoridades locais e 
provinciais, a exemplo do ofício encaminhado ao presidente da Província pelo juiz municipal de Ilhéus, Jerônimo dos Santos Quaresma, em 24 de novembro de 1840:

Levo a presença de V. Excia. O officio incluso que me dirigio Fr. Ludovico de Liorne Vigario da Freguesia de S. Pedro d'Alcantara, no qual faz aceitadas refleçoens a respeito dos ataques que tem sofrido do Gentio Barbaro; os habitantes daquella ditta povoação, havendo já commetido um assacigno do Indio José Victorio, estando este trabalhando em sua roça, alem de outras tentativas de mal fazer athé o ponto de entrarem na Povoação no sillencio da noite, e com violência tentarem arrombar as paredes das casas, e não conseguirão seo intento pelo alvoroço em que ficou toda a Povoação, refugiando-se todo Povo na Igreja, e disparando-se imenços tiros de espingardas $[\ldots]^{8}$.

Muito embora os aldeados e não aldeados daquela região mantivessem contato, visto que, como já explicitamos anteriormente, os aldeados de Ferradas mantinham um frequente trânsito na região, havia, naquela realidade de encontros, lugares sociais distintos entre os aldeados e os não aldeados, sobretudo entre Camacãs e Botocudos. Os primeiros correspondiam à maior parte da povoação do aldeamento, como as fontes por vezes testemunham; e os Botocudos se configuravam nos principais atores descritos pelas autoridades como dificultadores do processo colonizador.

Acontece em Ferradas o que Barth chamou de construção da fronteira étnica, que se faz com base no encontro e não na separação dos grupos e pessoas: "as distinções

8 APEB; Seção Arquivo Colonial e Provincial; Série Judiciário, maço 2395-1, ano 1840. 
de categorias étnicas não dependem de uma ausência de mobilidade, contato e informação" ${ }^{\prime \prime}$. Os grupos indígenas aldeados e não aldeados se encontravam em constante movimento e interação, no entanto, o encontro demarca fronteiras sociais entre aqueles grupos, situando-os em estado de conflito e oposição, porque também eram opostos os interesses que permeavam o encontro. Dessa forma, observamos, de um lado, índios não aldeados se utilizando do recurso disponível naquele momento: a força, no intuito de barrar, em alguma medida, o avanço de terras cultivadas pela agricultura que, por sua vez, lhes roubava a mobilidade num território que era seu legitimamente. De outro lado, os aldeados: eles assumiam a defesa daquele espaço territorializado ao qual, de forma reconfigurada, atribuíam um sentido de pertença.

Na perspectiva de Mary Louise Pratt, a fronteira não é o lugar que marca limites e divide territórios, pois se define como "zona de contato", constituído pela ação dos sujeitos; espaço que se define, redefine-se e está em constante movimento, conforme os conflitos estabelecidos entre os diferentes sujeitos históricos que se "encontram" naquela situação específica, "frequentemente dentro de relações radicalmente assimétricas de poder"10.

Em correspondência enviada por frei Ludovico ao juiz de paz de Ilhéus, no dia 13 de julho de 1840, ele volta ao assunto da violência e mantém o mesmo teor do ofício acima explicitado. Relata, de forma minuciosa, o assassinato de um dos aldeados, atribuído aos Botocudos habitantes daqueles territórios:

9 BARTH, Frederik. "Grupos étnicos e suas fronteiras". In: POUTIGNAT, Philippe; STREIFF, Jocelyne. Teoria da etnicidade: seguido de grupos étnicos e suas fronteiras. 2. ed., São Paulo: Ed. Unesp, 2011, p. 188.

10 PRATT, Mary Louise. Os olhos do império: relatos de viagem e transculturação. Bauru, São Paulo: EDUSC, 1999, p. 32. 
no dia três, visto que faltava hum Indio chamado Jozé Antonio e sabendo que no dia antecedente estava sozinho na sua roça, forão homens em procura delle, e acharão no mato, poucos passos distantes da mesma roça o seu corpo morto, transpassado de huma flecha, que do ombro esquerdo sahio a ponta fora do peito[... $]^{11}$.

O frade continua seu relato ao juiz de paz da vila de Ilhéus, descrevendo a forma como o corpo havia sido encontrado:

Tinha o rosto desfigurado por dous golpes de facão, que os Bárbaros lhes derão, hum entre os olhos e o nariz, e outro entre o nariz e a boca, profundos em modo que o queixo estava pendurado. Lhe tirarão fora o olho direito, lhe cortarão a pelle em roda do mesmo olho com toda a sobrancelha, tudo levarão consigo, e juntamente o facão, único ferro, que tinha o desgraçado defunto ${ }^{12}$.

Os índios aldeados em São Pedro de Alcântara eram, em sua maioria, Camacãs. Mas, na aldeia eles estavam misturados aos Guerens e também conviviam com os Pataxós e Botocudos nos espaços limítrofes do aldeamento. Pode-se explicar, em parte, a "violência" dos botocudos não aldeados sobre aqueles aldeados, considerando as observações de Maria Hilda Paraíso, para quem “os Kamacã-Mongoió não mantinham boas relações com os Pataxó e com os Botocudos que, ao que parece,

11 APEB; Seção Arquivo Colonial e Provincial; Série Judiciário; maço 2395-1; ano 1840 .

12 Idem. 
haviam se deslocado para seu habitat tradicional"13. A autora afirma ainda que "essa beligerância foi usada pelos conquistadores e colonos para transformá-los em combatentes dos outros grupos [nas regiões de] Nova Viçosa, Caravelas, Belmonte, Mucuri e ao longo do rio Pardo"14. No entanto, naquele espaço e naquele momento, o que estava em jogo não era, preponderantemente, a histórica rivalidade entre as etnias. Os botocudos pareciam calcular muito bem suas ações, pois o relato deixa claro que estavam em busca de ferro e o estado no qual o corpo foi encontrado sugere que aqueles homens, na realidade do contato, pretendiam demarcar os limites da ação colonizadora. Deixar o corpo de um dos aldeados mutilado sugere se tratar de um recado àquelas autoridades, portanto, uma ação politicamente calculada pelos indígenas categorizados de "Botocudos"15.

Outra estratégia dos Botocudos foi cercar o aldeamento e amedrontar a população aldeada, visto que, quatro dias após o "crime" ter sido cometido, mais precisamente "no dia sete antes da madrugada descobriose que huns delles estavão escondidos em hum quintal entre huns pez de café, o que se averiguou pelo rosto, que se vio quando o dia se for claro"16. Ludovico segue o seu

13 PARAÍSO, Maria Hilda Baqueiro. Op., cit., 1998, p. 279.

14 Idem, ibidem

15 Os botocudos são assim referidos: são aqueles que não aceitam o aldeamento e/ou dificultam a ação colonizadora, já quando aldeados, eles são os guerens. A documentação traz o termo Gueren apenas para designar os índios aldeados, transferidos do Almada para Ferradas, depois disso, os encontramos genericamente denominados de Botocudos em todos os registros documentais. Portanto, optamos por manter o termo botocudo no desenvolvimento do capítulo, pela impossibilidade de diferenciar os grupos indígenas designados sob este termo nas fontes.

16 APEB; Seção Arquivo Colonial e Provincial; Série Judiciário; maço 2395-1; ano 1840. 
relato sobre a morte do índio José Antônio, explicitando que "tirarão duas flechas ao fallecido, que huma se achou no corpo, e a outra no chão e pelo feitio dellas se conhece que os Bárbaros são Botocudos [...]. He claro que não são Patachós [...] pela certeza de que em vinte e quatro annos [...] nunca estes fizerão mal"17. Nesse episódio, foram os camacãs os principais atingidos, no processo de delimitação dos interesses entre aldeados e não aldeados. No entanto, nem sempre era esse o desfecho dos conflitos naquela "zona de contato".

Em correspondência de 25 de abril de 1842, o juiz municipal interino da Vila de Ilhéus, Antonio Lopes Benevides, assim se reportou à presidência da Província da Bahia:

17 Idem.

Tendo hua horda de índios selvagens hostilizando atraiçoando e progressivamente, há quazi cinco annos a povoação de S. Pedro de Alcantara, chove da estrada do Sertão para esta $\mathrm{V}^{\mathrm{a}}$ habitada por laboriozos índios Camacans, cathequizados, e dirigidos pelo muito Respeitável Pe Me Fr. Ludovico de Leorne, já vindo aquelles bárbaros cercar a Povoação a ponto vedarem aos ditos habitantes de hirem as suas rossas, que uzão roubar, já flechando-os e arrombando suas cazas do que tem rezultado mortes e ferimentos; accontece renovarem ultimamente seos insultos e crueldades, o que obrigou alguns dos mesmos Camacans a sahirem em seguimento, mas tendo sido descobertos no meio das matas impunhavão os bárbaros [as] flechas de que sem duvida aquelles seriam victimas se em defeza própria não lhes descarregassem as armas que levarão, 
occasionando a morte de quatro selvagens e apprehenção de cinco meninos, que não poderão fugir ${ }^{18}$.

Diferentemente do episódio anterior, nessa ocasião os camacãs aldeados, numa postura aparentemente defensiva, avançam sobre os Guerens e estando em posse de armas de fogo mais eficazes, do ponto de vista bélico, garantem um desfecho favorável aos seus interesses. Assim, obtiveram a manutenção da segurança do espaço de povoamento do aldeamento e garantiram a segurança em seus espaços de trabalho agrícola. Podemos observar que o aldeamento se caracterizava por ser um espaço reconfigurado pelos aldeados e de seu pertencimento a partir da experiência cotidiana da colonização. Nas palavras de Pratt, o processo de transculturação é um fenômeno típico da "zona de contato", e de acordo com a autora, "se os povos subjugados não podem controlar facilmente aquilo que emana da cultura dominante, eles efetivamente determinam, em graus variáveis, o que absorvem em sua própria cultura e no que o utilizam". ${ }^{19}$ Inferimos, portanto, que a defesa do aldeamento e de suas plantações em parte derivava do sentimento de pertença àquele mundo reconfigurado, animando as ações de defesa do espaço do aldeamento por parte dos aldeados de Ferradas. Obviamente essa afirmação deve ser relativizada, pois há outras chaves de compreensão possíveis para essa situação.

Havia naquela situação também o jogo de interesses dos não índios; ou seja, das autoridades governamentais e religiosas que exerceram um papel na tomada de decisão de

18 APEB; Seção Arquivo Colonial e Provincial; Série Judiciário; maço 2395-1; ano 1842.

19 PRATT, Mary Louise. Op., cit, p. 30-31. 
confronto. Essas autoridades forneciam armas aos índios, e se ocorria o deslocamento organizado do aldeamento para as matas, era porque os agentes da colonização consentiam e talvez incitassem. Como bem lembrou Paraíso, no processo da colonização a rivalidade beligerante entre Camacãs, Pataxós e Botocudos era utilizada e, dentre outras localidades afetadas, figura o rio Pardo, região de interesse dos colonos da região.

Notamos, contudo, que não era apenas ao longo do rio Pardo que os conflitos aconteciam, pois se estendiam também ao longo do rio Cachoeira ou Colônia. O agenciamento da guerra, nesse sentido, era bastante paradoxal. A guerra era empreendida tanto pelos índios não aldeados, para de alguma forma impedir o avanço da colonização sul baiana, quanto pelos aldeados, que ao mesmo tempo queriam defender o seu espaço de sobrevivência e segurança, bem como atuar apoiando os interesses da ação colonizadora.

É bem verdade que, no processo de expansão da colonização posta em prática no sul da Bahia oitocentista, os Pataxós e, sobretudo, os Botocudos foram violentamente perseguidos. A eles foram atribuídos discursos e práticas condizentes com a imagem de "natureza" de animalidade e fereza. Eles muitas vezes agiram e reagiram também com intensa violência, atacando e matando. Contudo, é igualmente verdadeiro que colonizadores e botocudos não eram, o tempo todo, incondicionais inimigos. Para além do discurso de fereza e demonização dos botocudos veiculado por autoridades governamentais e capuchinhos que atuavam na região à época - a realidade na situação de contato era bem outra.

Nesse sentido, apresentaremos, dentre as informações colhidas nos documentos oficiais trocados entre autoridades de Ilhéus e a capital da província, três casos 
nos quais Pataxós, Botocudos, colonos e autoridades locais atuaram naquela "zona de contato", negociando, de diferentes formas, os seus interesses e o estabelecimento de aldeamentos. Os não aldeados agiram não só pelo viés da guerra. Naquele mundo multifacetado, também agiram e reagiram ao processo de expansão territorial daquelas paragens de forma sutil, aceitando ou requerendo a vivência no mundo territorializado, mas estabeleciam, nesse processo, e conforme era possível, os seus próprios interesses.

$\mathrm{Na}$ interpretação das fontes analisadas, é interessante perceber como se davam, na prática, as relações entre os Botocudos e as autoridades governamentais e religiosas. Enquanto em alguns relatos oficiais os botocudos e, em menor grau, os Pataxós figuravam com destaque no quadro dos problemas e dificuldades que emperravam o avanço do processo colonizador no sul da Bahia, sendo descritos como inúteis ao projeto nacional, em outros os mesmos atores são mencionados como agentes que pareciam conscientemente atuar no jogo, sabendo perfeitamente a hora de resistir ou de se aproximar, e os momentos propícios para fazer alianças e negociar.

Como bem definiu Nacuzzi, os espaços de fronteira indicam "una zona permeable, porosa, en constante reacomodamiento" ${ }^{20}$. Por isso, formou-se, também no sul da Bahia, uma teia complexa de interesses dos grupos étnicos, que era instável, permitindo a construção de relações interétnicas conflitivas e negociadas.

Convém ressaltar, portanto, que o cenário de atuação dos pataxós e botocudos no sul da Bahia foi um campo

20 NACUZZI, Lidia R. Introdução. In: LUCAIOLI, Carina P.; NACUZZI, Lidia R. (Orgs.). Fronteras: Espacios de interacción en las tierras bajas del sur de América. Buenos Aires: Sociedad Argentina de Antropologia, 2010, p. 8. 
minado, durante todo o século XIX. Dessa forma, frisamos a observação de Vânia Moreira, acerca da atuação bélica contra os botocudos do Espírito Santo, como um processo que nos permite, em algum grau vislumbrar a realidade dos não aldeados naquela "situação de contato" no sul baiano. No contexto de deflagração de guerra justa contra os Botocudos da Capitania do Espírito Santo, processo no qual os indígenas sofreram as retaliações violentas de um forte aparato militar, Moreira observa que os Botocudos daquela Capitania "foram agentes bastante conscientes dos limites e das possibilidades existentes para eles no cenário da guerra ofensiva" ${ }^{21}$. Portanto, a negociação e construção de alianças faziam parte do cenário regional. Como a autora frisa, mesmo que isso significasse possibilidades "desiguais e transitórias" 22 entre índios e não índios, não era uma situação atípica para aqueles sujeitos num contexto de vulnerabilidade. Inferimos que também não o era para os Pataxós e Botocudos que atuavam no sul da Bahia durante os anos coloniais e imperiais.

Desse modo, propomos pensar a ação dos botocudos, conhecidos pelo seu suposto caráter irredutível ao processo colonial no sul da Bahia, para além da ideia engessada da existência de uma fronteira rígida entre colonizadores e índios. Sugerimos, portanto, pensar aquela realidade de contato como processo que funcionou numa mão dupla. Assim, por meio da negociação, podemos perceber as reconfigurações étnicas dos botocudos que, estrategicamente, se inseriam nos espaços territorializados.

21 MOREIRA, Vânia Maria Losada. "1808: a guerra contra os botocudos e a recomposição do império português nos trópicos". In: CARDOSO, José Luís; MONTEIRO, Nuno Gonçalo e SERRÃO, José Vicente (Orgs.). Portugal, Brasil e a Europa Napoleónica. Lisboa: ICS. Imprensa de Ciências Sociais, 2010b, p. 404.

22 Idem, p. 406. 
Assim como na realidade do Espírito Santo, observada por Vânia Moreira, os Botocudos e Pataxós do sul da Bahia agiam conscientes dos limites que lhes eram impostos. Eles sabiam a hora de resistir conflitivamente, mas também se adaptavam à condição colonial quando necessário. Eles sabiam que o poder de fogo do colonizador era mais poderoso do que as armas de que podiam dispor. Portanto, muitas vezes, a arma de que dispunham com mais eficiência e que eles usavam a seu favor, era mesmo a negociação.

A negociação estabelecida entre índios e não índios na situação de contato no sul da Bahia, em algumas ocasiões era aberta e bem demarcada; em outras, contudo, a negociação se dava de forma sutil, construída no intercâmbio fluído entre aqueles dois mundos. Nossa argumentação pode ser confirmada pelo testemunho da correspondência de Antônio Dias de Miranda à presidência da província, em 6 de dezembro de 1826:

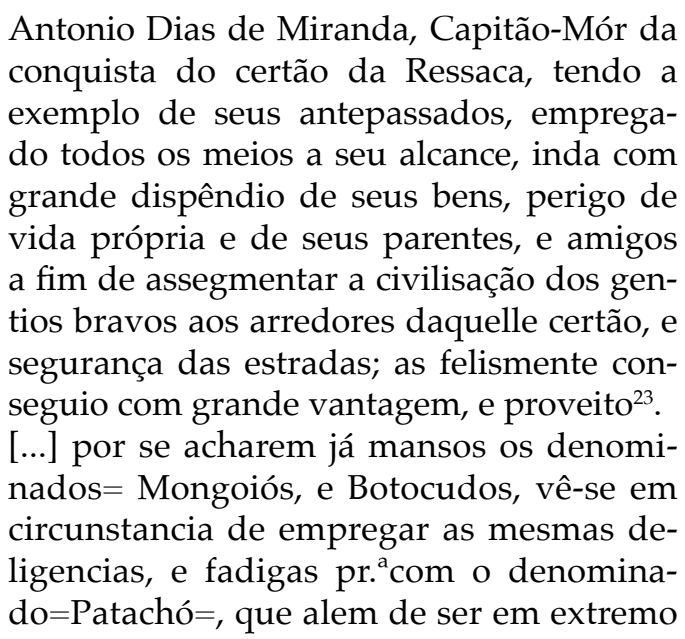

23 APEB; Seção Arquivo Colonial e Provincial; Série Agricultura; maço 4613; ano 1826. 
bravio, e numerozo, tem sempre vivido ceconcentrando nas montanhas mais [densas] esquivando-se de toda a comunicação, por isso, que elle mesmo de por si, vendo, que os indivíduos rezidentes debaixo do comando do supp.e, e mesmo este, tendo por muitas vezes precizão de passarem por suas habitações, sem o offender, temse aproximado aos recintos do dito certão da Ressaca, vindo até cassar junto as casas vizinhas das povoaçoens, sem offender a pessoa alguma, o que dá grandes indícios de se quererem domesticar ${ }^{24}$.

As famílias de Gonçalves da Costa e Antônio Dias de Miranda atuaram, historicamente, na região do rio Pardo na conquista dos sertões, no aldeamento dos camacãs ${ }^{25} \mathrm{e}$ combate violento aos Botocudos, como atesta Maria Hilda Paraíso $^{26}$. A região de Ilhéus e Conquista apresentava limites geográficos tênues, haja vista o esforço de ligação entre as referidas vilas pela abertura e conservação da estrada. Desse modo, a influência regional das famílias Costa/Miranda testemunha, mais uma vez, a relação estabelecida entre fazendeiros e autoridades locais e provinciais no sentido de garantir o bom êxito do projeto colonizador no sul da Bahia, durante o século XIX. Na referida correspondência, além de fazer um relato dos trabalhos prestados por sua família ao Governo Provincial naquela região, Dias de

24 APEB; Seção Arquivo Colonial e Provincial; Série Agricultura; maço 4613; ano 1826.

25 Segundo Maria Hilda Baqueiro Paraíso, 1998, p.279: Após tentativas frustradas de fazerem frente à conquista de suas terras, os Kamacã-Mongoió optaram por aceitar o aldeamento e as relações de dominação impostas pelos conquistadores, destacando-se, dentre eles, a família de João Gonçalves da Costa.

26 PARAÍSO, Maria Hilda Baqueiro. Op., cit., 1992, p. 416-417. 
Miranda aponta para a possibilidade do aldeamento de um grupo de Pataxós que habitava as redondezas ocupadas por moradores não índios.

No relato do capitão-mor Dias de Miranda, os camacãs (Mongoiós) e os Botocudos da região aparecem como povos já "mansos". Entretanto, outras tantas correspondências do mesmo período e de décadas posteriores retratam um cenário contrário a essa descrição de povos amansados, principalmente com referência aos Botocudos. Como demonstraremos em outro tópico, houve um demasiado esforço em caracterizá-los como "selvagens" que emperravam o processo colonizador no sul da Bahia. No entanto, na correspondência citada acima, eles aparecem ao lado dos Camacãs como mansos, e os Pataxós como extremamente bravios. Isso demonstra claramente as contradições dos discursos gestados na esfera do poder local, que tinham como objetivo justificar e legitimar os seus interesses econômicos, principalmente demonizando os Botocudos, quando thes convinha.

Podemos ainda observar as relações sociais, na zona de contato do sul da Bahia, entre índios e não índios. O relato de Miranda deixa em evidência o trânsito dos diferentes sujeitos naquela região. Nesse processo, podemos inferir que os Pataxós mantiveram os limites entre seu mundo e o mundo do colonizador enquanto foi possível. No entanto, com o avanço da colonização, os limites geográficos entre eles inevitavelmente se imbricavam e começou a ser conveniente, para os pataxós, se aproximarem, sobretudo para a garantia de sua sobrevivência, segurança e permanência em seus territórios.

Para os fazendeiros e autoridades locais, a "domesticação" e o aldeamento dos Pataxós significava assegurar o sucesso do projeto colonizador naquelas paragens. Nas palavras de Dias de Miranda, "domesticar" os Pata- 
xós tinha "[...] unicamente em vista alongar a civilização daqueles povos, e fazer prosperar a cultura, o sucego dos habitantes de seu districto, e mais vesinhos, e a segurança das estradas" 27 .

Os pataxós se aproximavam e permitiam que os não índios se aproximassem do seu território. Miranda ressalta que se fazia necessário oferecer "presentes" aos Pataxós a fim de persuadi-los. Em documento anexo à correspondência analisada, Dias de Miranda especifica os produtos necessários para oferecer aos pataxós:

"Relação de que se fazem precisas para offertar aos indígenas denominados Patachó a fim de os domesticar" 28

\begin{tabular}{|l|l|}
\hline Discriminação & Quantidade \\
\hline Machados & 40 \\
\hline Facoens ordinários & 40 \\
\hline Facas flamengas & 50 \\
\hline Carapuças vermelhas & 100 \\
\hline Missangas sortidas/massos & 24 \\
\hline $\begin{array}{l}\text { Pólvora, chumbo proporcionado } \\
\text { para segurança e deffeza das } \\
\text { pessaos que fazem precisas } \\
\text { empregar nesse serviço. }\end{array}$ & 1 barril \\
\hline $\begin{array}{l}\text { Dinheiro para pagamento dos } \\
\text { condutores das cargas, e mais } \\
\text { despezas, que ocorrerem até a } \\
\text { ultimação da empreza.c }\end{array}$ & 1000 réis \\
\hline
\end{tabular}

Marta Amoroso ressalta que, no Paraná, o Barão de Antonina elaborou e encaminhou ao governo o plano

27 PARAÍSO, Maria Hilda Baqueiro . Op., cit., 1992, p. 416-417.

28 APEB; Seção Arquivo Colonial e Provincial; Série Agricultura; maço 4613; ano 1826. 
direcionado à redução dos kaiowá. O plano seria colocado em prática pela atuação capuchinha, responsável pela catequese nos aldeamentos da região. O plano de Antonina consistia em "criar entre os índios as necessidades do homem civilizado, facilitando-lhes para isso os meios necessários"29. Amoroso sintetiza, em seu trabalho, que o plano de Antonina para as populações indígenas paranaenses visava provocar a "mudança de hábitos" dos índios, através da "conquista do paladar". Tratava-se de persuadi-los a ingressarem nos aldeamentos, oferecendo brindes, com o intuito de acostumá-los aos modos de vida do não índio e implantar neles a necessidade do consumo dos produtos ocidentais ${ }^{30}$. As práticas voltadas para a persuasão dos índios eram estratégias comuns às províncias e conhecidas desde os primórdios da colonização. Assim, Dias de Miranda, ligado aos interesses pecuários de Gonçalves da Costa no sertão da Ressaca, se utilizou da estratégia de sedução dos índios, a fim de aldeá-los.

Note-se, contudo, que dentre os gêneros a serem disponibilizados aos Pataxós a fim de atraí-los à condição aldeada aparece o "ferro", sobretudo ferramentas e armas como facas e machados. Seguindo a reflexão sugerida por Amoroso, tomada de empréstimo da etnologia, é importante realizar a leitura da "abertura para o outro", ou seja, pensar os possíveis interesses indígenas na situação de contato ${ }^{31}$. Marta Amoroso ressalta que os índios não se deixaram seduzir por qualquer coisa ou sem razão.

29 Antonina, apud AMOROSO, Marta Rosa. Catequese e evasão: Etnografia do aldeamento indígena São Pedro de Alcântara, Paraná (1855-1895). Tese de doutorado. Universidade de São Paulo, 1998, p. 66.

30 Idem, p. 64.

31 Idem, p.63 
Pois, da mesma forma que eles aceitavam os brindes no contato com o colonizador, eles igualmente se negavam a consumir os produtos ocidentais, em outras ocasiões, como forma de resistência cultural ${ }^{32}$. Nessa perspectiva, a estratégia colonizadora de sedução pode ser interpretada também considerando a forma como os índios vivenciaram essa realidade. Deve ser feita pelo viés da negociação no contexto do contato, processo no qual se deve fazer a leitura da abertura ao outro pelo caráter, prioritariamente, da apropriação e ressignificação.

A situação que envolve os Pataxós do sul da Bahia sugere que a separação entre os dois mundos, dos índios e não índios, era cada vez mais invisível. Tentava-se persuadir os Pataxós mediante oferta de "presentes" e, ao mesmo tempo, notamos que se eles ofereciam ferramentas era porque, em alguma medida, os Pataxós envolvidos naquela realidade se interessavam por tais objetos. Portanto, o intercâmbio entre índios e não índios acontecia também fora do perímetro do aldeamento, pois, antes mesmo de aldear-se, os Pataxós pareciam já comungar de outros saberes e do desejo de incrementar suas técnicas com as ferramentas dos colonizadores. Essa perspectiva era agenciada pelo estreitamento do convívio com o não índio e com os índios aldeados no mundo da colonização. Os espaços territoriais em comum se transformavam, portanto, em espaços de sociabilidades entre os diferentes sujeitos que ali se encontravam.

$\mathrm{O}$ segundo caso escolhido refere-se à negociação estabelecida entre Botocudos e o juiz municipal de órfãos de Ilhéus, Antônio d'Aguiar Silva, entre 1843 e 1845, sobre a instalação dos mesmos em um aldeamento.

32 Idem, p. 69. 
Diferentemente da sutileza apresentada na negociação envolvendo os Pataxós, nesse caso, o caráter de negociação entre autoridades e Botocudos fica bastante em evidência.

Em correspondência do dia 23 de maio de 1843, o juiz municipal de órfãos e delegado da Vila de Ilhéus, Antônio d'Aguiar Silva, se reportou ao Presidente da Província da Bahia, o desembargador Joaquim José Pinheiro de Vasconcellos, com o fim de relatar a negociação com um grupo de botocudos inas da região, acerca do seu estabelecimento em um aldeamento:

\begin{abstract}
A vinte e três do corrente veio ter commigo o Muito Reverendo Missionário Fr. Ludovico de Liorne anunciando-me que lhe tinhão apresentado dezesseis Botocudos das margens do Rio Pardo acompanhados de Victorio da Cunha Soares, por quem os tinha mandado convidar, e que exigião alguns prezentes, e dezejavão conhecer-me, por que lhes dissera que era necessário entender-se commigo para satisfaze- $\operatorname{los}^{33}$.
\end{abstract}

Por intermédio de Vitório da Cunha Soares, os Botocudos aceitam conversar com frei Ludovico. Contudo, dois aspectos desse fragmento são elucidativos acerca do desenrolar da negociação. Em primeiro lugar, ao que tudo indica, eles foram se encontrar com o frade de forma já organizada, pois aqueles dezesseis Botocudos estavam falando em nome de uma população maior; eram, portanto, seus representantes. Em segundo lugar, um ponto que é muito interessante: frei Ludovico aparece como figura-chave nesta negociação, confirmando mais uma vez a centralidade e importância do seu papel político, no que

33 APEB; Seção Arquivo Colonial e Provincial; Série Judiciário; maço 2395-I; ano 1843. 
envolvia a questão indígena na região sul da Bahia. Ludovico manda convidar os índios, negocia com eles e intermedia o desenrolar da negociação entre os índios e o juiz de órfãos de Ilhéus.

A narrativa documental segue nos dando pistas do interesse principal do governo local acerca da negociação com os referidos Botocudos. D'Aguiar Silva explicita ao Presidente Vasconcellos que,

[...] havendo a tribu denominada Noc-noc pelos Botocudos continuado suas incursões sobre as Ferradas e passando desta para baixo ameaçando já os Fazendeiros da Caxoeira de Itabuna, julguei que devia aproveitar os apresentados e seu guia para unidos com alguns Camacães sob a direção do Reverendo Missionário, que a isso com o seu ardente zelo verdadeiramente Evangélico promptamente se prestou, entrarem nas mattas e ver se podiam conseguir o aldeamento daquella tribu assim nocivo, ou pelo menos quando o recuzassem, aprehenderem alguns, e entrega-los ao dito Missionário para que attrahidos pela sua maneira de os tractar [cressem] no conhecimento de que não somos seus inimigos, antes dezejamos para elles as vantagens da vida social, e por este meio servimo-nos então dos aprehendidos para persuadi-los, e tomar amigos tão perigozos inimigos, ou quando menos evitar suas hostilidades ${ }^{34}$.

Nesse momento dos acontecimentos, a negociação acerca do aldeamento parecia exitosa, pois os inas já estavam mantendo relações com as autoridades locais e

34 APEB; Seção Arquivo Colonial e Provincial; Série Judiciário; maço 2395-I; ano 1843. 
prestando serviço ao governo imperial naquelas paragens antes mesmo da sua instalação em aldeamento, como deixa claro o fragmento acima. Juntamente com os camacãs de Ferradas, os 16 Botocudos inas ficaram incumbidos de persuadir ou aprisionar os botocudos da tribo noc-noc. Podemos, portanto, suscitar algumas reflexões importantes com relação ao fragmento destacado.

Mais uma vez, podemos perceber a complexidade das relações estabelecidas naquela "zona de contato". A realidade era fluida: à medida que um grupo de Botocudos era descrito pelo juiz de órfãos como "perigozos inimigos", com outro grupo construía-se aliança e negociava-se possibilidade de aldeamento. Igualmente delicada é a complexidade observada entre os diferentes grupos indígenas naquela situação específica. A relação é de conflito e de sobreposição de um grupo ao outro, processo intermediado pelos interesses que moviam autoridades de Ilhéus e botocudos em processo de negociação. Estava em jogo, naquele contexto, a manutenção da viabilidade do projeto colonizador em Cachoeira de Itabuna, visto que a maior preocupação das autoridades locais, acerca dos ataques da tribo noc-noc, dizia respeito à garantia de segurança aos fazendeiros de Cachoeira de Itabuna.

Outro aspecto muito revelador nesse fragmento, diz respeito aos direcionamentos da prática indigenista no sul da Bahia, em meados do Oitocentos, com relação aos índios resistentes ao processo colonizador, baseada na prática de apresamento, como evidencia a documentação. Fica nítido que a orientação das autoridades em relação à tribo noc-noc era o aprisionamento, caso se recusassem a aldear-se.

Ainda nos meandros da negociação, o juiz segue o seu relato, ao Presidente da Província, explicando que os índios, representados pelos 16 Botocudos, pretendiam aldear-se no retorno da ação contra os noc-noc: 
[...] Partirão hontem para esse feito muito satisfeitos comigo os apresentados, e o Missionário, promettendo-me aquelles que não offendirião aos Noc-noc e farião que viessem aldear-se, e que elles mesmos querião vir também para os governar, e que concluída a deligência a que hião, voltarião para thes dar vestidos para suas mulheres, e irião busca-los, e a seus parentes para cá. [...] Não menos [il.] a notícia do rezultado do que a aprovação de V. Ex $x^{a}$ sobre o que hei feito, e o que intenciono fazer se realizarem minhas esperanças, isto he, colloca-los no logar denominado Boqueirão mas se quizerem, visto já ter alli uma capella, posto que coberto de palha e algumas cazas ${ }^{35}$

A negociação estabelecida entre Botocudos e autoridades governamentais de Ilhéus se dá num jogo de interesses bem definidos. Como já mencionamos, as práticas violentas e coercitivas empregadas contra os botocudos desde a decretação da guerra justa, em início do século XIX, impunha a eles uma vivência instável nos territórios de expansão colonizadora. Garantir a própria sobrevivência e permanência em seus territórios muitas vezes passava pela disponibilidade da vivência nos aldeamentos. Inferimos, portanto, que os Botocudos da região de Cachoeira de Itabuna, de forma consciente e organizada, dispuseram-se a viver em aldeamentos como uma forma de resistir por outros meios: o da adaptação e ressignificação da própria vida. Vale lembrar que os Inas em negociação com Ludovico e o juiz de órfãos representam um grupo maior, vez que os 16 representavam os demais "parentes".

35 APEB; Seção Arquivo Colonial e Provincial; Série Judiciário; maço 2395-I; ano 1843. 
No dia 30 de junho de 1843, em documento anexo ao despacho da Tesouraria Provincial, o presidente da Província da Bahia Francisco José de Souza Soares d' Andréa, liberou verba para articular a ação planejada contra os noc-noc a pedido do juiz de órfãos de Ilhéus:

[...] inteirado de se lhe haverem apresentado, por intermédio do Missionário Fr. Ludovico de Leorne, 16 Botocudos das margens do Rio Pardo, e de, sob a direção deste mesmo Missionário empregados por Vosmicê sobre a tribu denominada Noc-noc que continua em suas incursões contra Ferradas, lhe authoriso, conforme pede, para as despesas que se fiserem indispensavelmente necessária com semelhante deligência ${ }^{36}$.

Em correspondência de 4 de fevereiro de 1845, o mesmo juiz de órfãos, Antônio d' Aguiar Silva, registra a informação de que depois de autorizado o estabelecimento do aldeamento pelo Presidente da Província, em junho de 1843 , se fazia necessário cumprir a exigência dos botocudos inas acerca da presença de um padre no estabelecimento:

[...] enviada que lhes fosse a noticia de que aqui se achava o desejado Padre, mandarão dizer-me que depois da Lua cheia seguinte verião recebe-lo. Com effeito apparecerão quarenta, e He inexplicável a satisfação que mostrarão quando lhes aprezentei o Missionário Fr. Francisco Antonio de Falerna, que não menos zelo mostra pela causa desses mizeráveis. Pedirão roupa para si, para os

36 APEB; Seção Arquivo Colonial e Provincial; Série Judiciário; maço 2395-I; ano 1843. 
outros que não vierão, e suas mulheres e filhos, e instrumentos agrários ${ }^{37}$.

Se, por um lado, o governo imperial manifestava interesse no aldeamento dos indígenas que ocupavam os espaços a serem colonizados, como fica evidente na fala do juiz de órfãos, "Ordenei-lhe que procurasse estabelece-los o mais próximo possível da estrada desta Villa para o interior ${ }^{\prime \prime 3}$, por outro lado, os índios muitas vezes também escolhiam viver a realidade do aldeamento, mas não como objetos passivos de tal processo. As fontes testemunham que eles estavam açodados pelas guerras e perseguições, mas que procuravam manter o comando das negociações em curso e de forma organizada, ou seja: primeiramente, foram eles que manifestaram desejo de aldear-se; em segundo lugar, aparentemente, eles escolheram o lugar da instalação da aldeia, pois o juiz deixa claro que os instalaria no lugar chamado "Boqueirão", caso eles quisessem; em terceiro, determinaram quando iriam buscar o missionário para o estabelecimento do aldeamento; por último, partiu dos próprios índios o interesse em ter um missionário.

As estratégias dos Botocudos do sul da Bahia não eram novas ou estranhas no mundo colonial. John Monteiro observa que, no período colonial, momento de implantação das "diversas formas de integração do índio na sociedade escravista" ${ }^{\prime 3}$, as populações indígenas sem condição de reproduzir seu modo de viver das aldeias,

37 APEB; Seção Arquivo Colonial e Provincial; Série Judiciário; maço 2395-I; ano 1845.

38 APEB; Seção Arquivo Colonial e Provincial; Série Judiciário; maço 2395-I; ano 1845 .

39 MONTERIO, John Manuel. Op., cit., 1994, p. 170. 
procuraram construir seus próprios espaços dentro da nova realidade que se lhes apresentava na sociedade colonial. "Esta busca, embora produzisse resultados no mais das vezes ambíguos, manifestava-se tanto na luta cotidiana pela sobrevivência quanto nas múltiplas formas de resistir". ${ }^{40}$

Também à luz das reflexões de Regina Celestino de Almeida sobre as aldeias coloniais do Rio de Janeiro, na realidade dos estudos que envolvem os índios em situação de contato, no século XIX, a autora observa que eles muitas vezes se interessavam pelas mudanças e, em outras, se aproveitavam da condição de índios aldeados para garantir seus próprios interesses. Essa estratégia não passava apenas pela prática de requerimento de direitos à terra através de processos jurídicos, estratégia demonstrada em muitos estudos indígenas atuais. Podemos observar, no sul da Bahia, os Botocudos se valendo estrategicamente da vivência nos aldeamentos como forma de manter sua permanência em seus territórios. Requeriam o aldeamento e aceitavam a condição de índios aldeados para permanecer em suas terras, dali podendo entrar e sair e continuar a ter acesso a um perímetro maior do que os limites dos aldeamentos. ${ }^{41}$ Não é possível dizer que os índios que se submetiam ao aldeamento construíram uma identidade de aldeados, contudo, podemos aventar que, para os Botocudos requerentes, ter um religioso no aldeamento significava, em algum grau, manter a legitimidade

40 Idem, ibidem.

41 LISBOA, Balthazar da Silva. Op., cit., p. 207-209: Carta de Ludovico a Lisboa, de 1819, na qual ele relata que os índios de Ferradas, depois de aldeados, entravam e saiam do "sítio"; em outra carta - nota: 96 do capítulo II-, de 1829, o mesmo Ludovico deixa claro que os índios mantinham um trânsito entre o aldeamento e outras aldeias mais ou menos independente. 
do novo lugar social no qual estavam inseridos, pois como acompanhamos ao longo deste estudo, a figura dos frades capuchinhos era direcionadora e central no projeto de colonização, naquela região.

Dentre os três casos de negociação entre índios e autoridades com o propósito de estabelecimento de aldeamentos na região sul da Bahia, o último diz respeito à solicitação de outro grupo de Botocudos, representado pelos índios Narciso, Miguel e José Antônio:

Exige V. Ex ${ }^{a}$ por despacho de 17 de Agosto ultimo nos documentos que devolvo, que informe acerca de hum requerimento de Indios Botocudos, que se dizem moradores nas margens do Rio Pardo e adjacências, pretender hum terreno entre o Riacho Catulé e de S. Pedro, afim de formarem ahi hua aldêa, que poderá prestar aos navegantes do Rio Pardo sustento e auxilio de braços. ${ }^{42}$

De imediato, temos a contrapartida oferecida pelos botocudos para o cumprimento de sua solicitação ao governo provincial. Os índios solicitaram aldear-se e para tanto, ofereciam sua mão de obra para o importante trabalho de navegação do rio Pardo. A transformação do rio Pardo em rio navegável e em via de comunicação e transporte exigia a existência de "canoeiros", pois, sem isso, o acesso às diferentes localidades da região se tornaria quase impossível. Essa demanda poderia ser satisfeita pelos índios, que sabiam cumpri-la com propriedade e habilidade. Eles demonstram ter consciência da importância de sua mão de obra naquele ramo de trabalho e se valem disso para assegurar o seu interesse.

42 APEB; Seção Arquivo Colonial e Provincial; Série Judiciário/juízes de Tl héus; maço 4611; 26 de novembro de 1849. 
Em 26 de novembro de 1849, Manoel Inácio de Lima, Diretor Geral dos Indios da Província da Bahia, em resposta ao ofício a ele dirigido pelo presidente da província esclarece:

[...] Tive portanto de dirigir-me a Frei Ludovico, que mandou-me o officio junto datado de 28 de setembro deste corrente anno, dizendo ser estes três Botocudos os autores do requerimento conhecidos e por V. Ex $x^{a}$. recomendados ao Doutor Villaça Juiz Municipal de Canavieiras para os coadjuvar na abertura do Sítio, ou lugar da dita aldêa, o qual He sadio, fértil, e está ainda totalmente diserto; que esses Indios tem de regressar a esta Cidade, e então d'elles saber-se-há do numero d'individuos e as demais informações, que thes tinha exigido para satisfazer a requisição de V. $\mathrm{Ex}^{\mathrm{a}}{ }^{4}{ }^{3}$

Com o seguimento das negociações, em novembro do mesmo ano, Manoel Inácio de Lima reporta à presidência da província as deliberações acerca da instauração da nova aldeia:

[...] os três Botocudos Narciso, Miguel e José Antônio com seu guia Manoel Lima, os quaes devendo ser acompanhados de hua ordem positiva do Governo, afim de que lá chegados, mandem sua gente para Canavieiras em procura de Frei Ludovico, que lá os espera; e hum rol de objectos necessários para a nova aldeia do Espírito Santo. São alguns instrumentos agrários, e roupas para quarenta cazaes. Permitta V. Exa ${ }^{\mathrm{a}}$, que note a omissão de algumas terras e de outros instrumentos

43 APEB; Seção Arquivo Colonial e Provincial; Série Judiciário/juízes de Ilhéus; maço 4611; 26 de novembro de 1849. 
muito necessários para as construções indispensáveis para a fundação de hua aldêa, como se obterão taboas feitas a machado, enxada e fouces? ${ }^{44}$.

Na sequência de nossa análise acerca da negociação entre os três Botocudos e as autoridades governamentais, Inácio de Lima conclui que lhe cabia tão somente deliberar as questões práticas e oficiais para o cumprimento da determinação presidencial, em atendimento ao requerimento dos botocudos, visto que os seus preparativos já haviam sido acertados sob o aval do Presidente da Província:

\begin{abstract}
[...] A vista do que acabo de expor a V. Ex ${ }^{\mathrm{a}}$., os preparativos para essa nova Aldêa, como já tivessem tido começo de algua sorte, debaixo da protecção e influência de V. Ex ${ }^{a}$., restame tão somente conforme o decreto ${ }^{\circ} 426$, que me serve de regimento, officiar a [sua] excelentíssima [recomendação] pedindo-lhe quanto antes hum Missionário para a nova aldêa, o qual receberá desta Directoria Geral as instruções necessárias, para o que pretendo ouvir hua outra vez a Frei Ludovico ${ }^{45}$.
\end{abstract}

Esse caso é bastante elucidativo acerca do direcionamento das negociações entre índios e autoridades. As autoridades, aliás, eram muitas e variadas, pois envolvia a presidência e o diretor geral dos índios, o juiz municipal e frei Ludovico. Fica em evidência, mais uma vez, a atuação de frei Ludovico como importante interlocutor dos interesses regionais. Como bem demonstra a fala de Manoel Inácio de Lima, frei Ludovico participou da negociação,

44 Idem

45 APEB; Seção Arquivo Colonial e Provincial; Série Judiciário/juízes de Ilhéus; maço 4611; 26 de novembro de 1849. 
ao menos indiretamente; além disso, partiriam dele as instruções para o trabalho do missionário designado para a nova aldeia.

Também fica em evidência, na documentação, que, primeiramente, os índios demonstram interesse de aldear-se e oferecem sua mão de obra para o serviço de canoagem; contudo, o mais interessante é que, ao que tudo indica, eles viajam até o presidente da Província e negociam diretamente com ele, pois o Diretor Geral dos Índios esclarece que os Botocudos requerentes eram os "conhecidos" pelo presidente da província e "recomendados" por ele ao juiz de Canavieiras. Isso é muito significativo no que toca às agências indígenas no processo da colonização sul baiana, pois diante de uma hierarquia estabelecida para tratar dos assuntos indigenistas com o governo da Província, os índios se interessam em negociar diretamente com a autoridade máxima, o Presidente provincial.

A negociação estabelecida nessa ocasião demonstra, mais uma vez, que os índios não eram vítimas passivas e ingênuas no processo de expansão territorial da região sul baiana, tampouco os botocudos atuavam unicamente como inimigos inconciliáveis do governo e moradores locais, como pretendeu demonstrar o discurso oficial sobre a "fereza" deles, forjado por parte da documentação compulsada. Era porque apostavam também no jogo da negociação, que se tornava possível o aldeamento dos índios.

\subsection{O que era ser índio aldeado no Sul da Bahia? \\ Ressocialização dos grupos étnicos no processo de territorialização oitocentista}

A maior parte da população aldeada em São Pedro de Alcântara era da etnia Camacã, tendo em vista que as 
correspondências trocadas entre as autoridades locais e provinciais fazem maior referência a ela. "Era um grupo Macro-jê (...). Seu território tradicional localizava-se entre os rios de Contas e Pardo, (...) limitava-se a leste com o dos Pataxós, na altura do córrego da Piabanha, afluente da margem esquerda do rio Colônia ou Cachoeira". ${ }^{46}$

Freitas e Paraíso observam que os aldeados de Ferradas eram do grupo "Kamacã-Mongoió". Na Capitania e posterior comarca de Ilhéus, como frisa Paraíso, os Camacãs "são referidos por Kamacã-Mongoió, ao norte do rio Pardo; Kamacã Menian e Menian na área do Pardo, do Colônia e do Mucuri, e por Caranins em Nova Viçosa e Caravelas" ${ }^{\prime 4}$. Ainda segundo os autores, não se pode afirmar que as diversas denominações camacãs se devia às subdivisões dos grupos, ou ainda, se eram atribuídas pelos próprios Camacãs ou por terceiros.

Vale lembrar que um dos principais direcionamentos advindos da política colonial e que era colocado em prática também pela política indigenista imperial, nesse momento, era o incentivo à mistura de diferentes grupos e etnias indígenas nos aldeamentos de catequese. E desde pelo menos o Diretório Pombalino, também se incentivava a mistura de índios e não índios, pois "procurando assimilar definitivamente os índios aldeados, incentivava a presença de brancos nas aldeias" ${ }^{\prime 4}$. Com relação ao Aldeamento São Pedro de Alcântara, a documentação oficial não testemunha o convívio direto de índios e não

46 PARAÍSO, Maria Hilda Baqueiro. Op., cit, 1998, p. 278.

47 Idem, p. 279.

48 PERRONE-MOISÉS, Beatriz. "Indios livres e índios escravos: Os princípios da legislação do período colonial (séculos XVI a XVIII)". In: CUNHA, Manuela Carneiro da. (Org.). História dos índios no Brasil. São Paulo: Companhia das Letras, FAPESP, 1992, p. 119. 
índios neste espaço, muito embora possamos observar essa possibilidade a partir da análise do Quadro das aldeias dos índios da Província da Bahia, de 1861 (Anexo 2), em que são discriminadas as situações das terras dos aldeamentos que não eram cultivadas por índios, sugerindo, pois, que elas estavam sendo cultivadas também por colonos daquele local.

Como demonstramos no capítulo anterior, eram muito próximas e fluídas as relações estabelecidas entre aldeados e colonos na região do Aldeamento São Pedro de Alcântara. A documentação analisada permite demonstrar que a intenção oficial era a promoção da mistura de índios e não índios. Contudo, na realidade do Aldeamento São Pedro de Alcântara, os indígenas, através de suas agências, talvez tenham se mantido à parte da convivência com o branco no interior do aldeamento.

A prática advinda do Diretório Pombalino previa a mistura de índios e não índios nos aldeamentos. Mas, naqueles espaços, também coabitavam frequentemente grupos indígenas etnicamente distintos, como bem lembra Perrone Moisés ${ }^{49}$. O mesmo acontecia em São Pedro de Alcântara, no século XIX, onde coabitavam distintas e rivais etnias indígenas.

No caso do Aldeamento São Pedro de Alcântara, na ocasião de sua fundação, coabitavam Camacãs e Guerens, esses últimos denominados também de Botocudos, que eram grupos historicamente rivais dos Camacãs naquelas paragens do sul da $\mathrm{Bahia}^{50}$. Por conseguinte, nos anos iniciais do funcionamento do aldeamento, podemos perceber alguns limites demarcados na convivência entre aqueles

49 PERRONE-MOISÉS, Beatriz. Op., cit., p. 119.

50 PARAÍSO, Maria Hilda Baqueiro. Op., cit., 1998, p. 279. 
diferentes grupos étnicos. Como observa Barth, as relações interétnicas "pressupõem uma estrutura da interação como essa: um conjunto de prescrições dirigindo as situações de contato e [...] um conjunto de proscrições sobre as situações sociais que impeçam a interação interétnica em outros setores". ${ }^{51}$

Desse modo, foram estabelecidas fronteiras étnicas e espaciais entre Camacãs e Guerens no espaço territorializado do Aldeamento, haja vista a descrição de frei Ludovico acerca dos aspectos da moradia daqueles grupos "Os índios do Almada são em numero de treze famílias, que formão treze casas arruadas defronte do Templo [...]; atraz da Igreja estão as casas dos Camacães em quadrado, que formão huma bonita praça" ${ }^{\prime 52}$.

Muito embora em São Pedro de Alcântara coabitassem Camacãs e guerens, além dos Pataxós que viviam no perímetro do aldeamento, sob a ótica das autoridades locais eles passavam a formar uma única massa, a dos aldeados em processo de civilização. E acima das divisões étnicas, linguísticas e culturais que existiam entre eles, em algumas ocasiões, também os percebemos manifestar-se segundo o lugar no qual estavam socialmente inseridos. Mostra disso é o fragmento documental no qual os índios de Ferradas, se valendo da situação de aldeados, solicitam a presença de um missionário no aldeamento. Assim, a mistura, aparentemente etnocida, se analisada pelo viés da etnogênese, permite perceber o processo não como perda de identidade étnica, mas como um processo de construção de pertencimento a outro lugar e papel social, através da agência indígena.

51 BARTH, Frederik. Op., cit., p. 197.

52 LISBOA, Balthazar da Silva. Op., cit., p. 207-209. 
Ao mesmo tempo em que os aldeados de Ferradas eram vistos como uma massa de índios úteis aos propósitos governamentais locais, eles mesmos, paulatinamente, se apropriavam dessa condição para seus próprios fins. Interessavam-se em manter o aldeamento em segurança, como já explicitado, bem como em aprender as técnicas e os usos da terra para fins da agricultura. Os registros documentais nos dão indícios de que, na nova configuração a que foram submetidos, à sua maneira, os aldeados tentavam se inserir e aproveitar as possibilidades apresentadas no espaço territorializado.

Os aldeados tinham noção da importância do seu trabalho na agricultura, bem como em trabalhos especializados, como a fabricação de canoas e a navegação e desobstrução dos rios. Aquelas pessoas "em situação de aldeamento", ao contrário de simples subjugadas aos propósitos do Estado, se deixavam "subjugar" e se apropriavam do mundo do aldeamento. Acerca disso, o documento dirigido à presidência da Província pelo Diretor da Aldeia de Ferradas, Egídio Luís de Sá, em 21 de maio de 1859, nos oportuniza analisar a atuação dos índios segundo essa perspectiva:

[...] Alguns desses homens, Exm. . Snr, possuídos já de algum cabedal de conhecimentos religiosos, e ja pelo amor ao trabalho, descerão a esta Villa reclamando [il.] de um padre $\mathrm{q}^{\prime}$ the fosse servir alli de bem reger suas acçõs, e lhes ministrasse os sacramentos q' offerece a Igreja a seus fieis, e dirigindo-se ao Doutor Juis municipal desta Villa, consta-nos $\mathrm{q}^{\prime}$ esse promethera a tal respeito representar a V. Excia. dando no q' podia para ora satisfaser-lhes com cuja resposta voltarão elles tristes, e bastante descontentes ${ }^{53}$.

53 APEB; Seção: Arquivo Colonial e Provincial; Série: Agricultura; maço 4612; ano 1859. 
Num primeiro olhar, o fato de os indígenas de Ferradas se deslocarem de sua aldeia até a Vila de Ilhéus, para reivindicar um missionário, pode parecer uma necessidade tutelar, característica dos moldes de convivência nos quais estavam inseridos. No entanto, se analisarmos essa situação à luz do contexto de insegurança da vida nos sertões, onde os aldeamentos se configuravam em espaços que asseguravam a sobrevivência e como um espaço que, de certa forma, permitia aos índios assegurar o domínio parcial sobre seus territórios, podemos então entender a postura dos aldeados como uma estratégica tentativa de acomodação ao mundo da colonização.

Ao se deslocarem até a Vila de Ilhéus para solicitar do juiz municipal providências acerca da entrada de um novo padre missionário na aldeia, para lhes garantir os sacramentos, os aldeados de Ferradas mais do que aceitarem o lugar de aldeados, se apropriaram do espaço do aldeamento como seu espaço de pertença, e talvez desejassem e escolhessem também assumir a identidade de cristãos. Também os Inas que negociavam a instalação de um aldeamento com o juiz de órfãos de Ilhéus, Antônio de Aguiar Silva, cujo desenrolar já acompanhamos anteriormente, solicitaram um padre e foram recebê-lo. Isso significa que eles adotaram a condição de aldeados catecúmenos e um novo lugar no mundo local; e isso estava relacionado a dois objetivos, pelo menos: garantir as suas terras e sua sobrevivência coletiva.

No estudo de Izabel Missagia de Mattos sobre os botocudos da Província de Minas Gerais, a autora observa "a incorporação do Outro" pelos atores pesquisados enquanto estratégia etnopolítica ${ }^{54}$. Ainda de acordo com a autora,

54 MATTOS, Izabel Missagia de. Civilização e revolta: os Botocudos e a catequese na Província de Minas. Bauru, SP: EDUSC, 2004, p. 26. 
trata-se de uma experiência "capaz de orientar os grupos indígenas impactados pela expansão da fronteira extrativista e agrícola". ${ }^{55}$ Nos termos de Mattos, podemos inferir a incorporação do "Outro" da fronteira sul baiana pelos camacãs, através dos símbolos religiosos (os sacramentos) do catolicismo, enquanto "estratégia etnopolítica" dos homens e mulheres que reconfiguram suas vidas a partir das experiências vivenciadas naquela situação específica.

Na realidade do contato, no sul da Bahia, durante a segunda metade do século XIX, ser índio aldeado significava, paradoxalmente, ter proteção e terra, mas também trabalhar ao lado dos colonos na positivação dos seus interesses, disponibilizando mão de obra na lavoura, pacificando a região e trabalhando ao lado dos religiosos e demais colonizadores na atração dos índios ainda não submetidos ao processo da territorialização. Quando os botocudos, os atores dos casos anteriormente analisados, negociavam a criação de aldeamentos na região, eles visavam o acesso à terra e também a segurança de viver no espaço do aldeamento; em contrapartida, estavam conscientes de que deveriam ficar a serviço do governo e dos locais. Enfim, eles fizeram guerra pelos seus espaços territoriais; sofreram coerções violentas; e, ao final, negociaram a própria rendição, conseguindo terra e oferecendo como moeda de troca o trabalho que mais poderia interessar a eles e aos colonizadores.

Vale ressaltar que, nas experiências diárias entre aldeados e missionários, não foram apenas os índios que mudaram e assumiram novas perspectivas diante do novo mundo. Os missionários, representantes dos interesses imperiais e dos particulares da região, mais próximos dos

55 MATTOS, Izabel Missagia de. Op., cit., p. 26. 
índios pela sua convivência diária, também se transformaram nesse processo. Eles se viram obrigados a mudar de estratégia, reconhecendo muitas vezes a incapacidade de gerir exclusivamente nos seus moldes a vida dos aldeados.

Acerca disto, recuperemos uma das correspondências de Ludovico de Livorno dirigida a Balthazar da Silva Lisboa. Nela, frei Ludovico se refere aos indígenas de Ferradas em tom de desapontamento e, ao mesmo tempo, reconhecendo a incapacidade de governar a vida dos índios estritamente nos moldes pensados pela política do aldeamento de catequese:

[...] Respeito á educação moral e civil destes Indios não posso estender minhas vistas acima da capacidade delles, e fóra dos limites destes bosques, pois a experiência me tem feito ver, que fora daqui ficão cheios de vícios, voltão vadios e mestres de impiedade: tal He a escola do século, bem diverso da pratica de como se considera na theoria ${ }^{56}$.

Dessa forma, não apenas os índios aldeados se transformaram; também aqueles que estavam ocupados da tarefa e dos mecanismos de aldeá-los foram transformados na zona de contato. Tal perspectiva permite pensar a realidade do contato de forma mais complexa e interativa entre as partes envolvidas. Além disso, os aldeados de Ferradas aparecem reconstruindo o seu mundo à maneira das expectativas de colonos e missionários, mas também frustrando-os na medida em que faziam escolhas próprias e punham limites quanto à governança de suas vidas.

56 LISBOA, Balthazar da Silva. Op., cit., p. 216-217. 


\subsection{Que "feras" são essas?}

No início desse capítulo, observamos os Botocudos protagonizarem negociações com o poder governamental. Nesse último tópico, propomos analisar o conjunto das correspondências selecionadas para este estudo, nas quais, diferentemente das relações de negociação entre colonizadores e índios não aldeados, os Botocudos são apresentados como implacáveis inimigos e dificultadores do projeto colonizador na região. No sul da Bahia, portanto, "feras" eram os índios que não aceitavam submeter-se ao aldeamento. Nessa perspectiva, nos ocuparemos, neste tópico do capítulo, de suscitar algumas reflexões possíveis acerca da construção de uma ideia de fereza e animalidade, por parte do governo de Ilhéus, sobre os Pataxós e Botocudos que resistiam ao processo colonizador. As falas do governo local tinham por objetivo conseguir do governo provincial, a disponibilização de verbas, armamentos, munições e ferramentas para a agricultura, dentre outros interesses. Como veremos adiante, quase todos os relatos de ataques dos botocudos, muitos de maneira expressivamente exagerada, eram acompanhados do pedido de verba ou qualquer outra requisição por parte do governo local ao governo provincial.

Como bem lembra Manuela Carneiro da Cunha, ainda no século XVI declaração papal reconhecia a humanidade dos índios. Mas de forma Paradoxal, no século XIX são levantados os questionamentos sobre a humanidade ou animalidade deles ${ }^{57}$. Portanto, nos anos imperiais, "a humanidade dos índios era afirmada oficialmente, mas privadamente ou para uso interno no país, no entanto, a

57 CUNHA, Manuela Carneiro da. Op., cit., p. 134. 
ideia da bestialidade, da fereza, em suma, da animalidade dos índios, era comumente expressa" 58 .

A demonização dos Botocudos justificava mais investimentos do governo imperial na política de aldeamento na primeira metade do século XIX, visto que, naquele momento, os interesses expansionistas recaíam sobre os territórios historicamente habitados por populações resistentes ao processo colonizador. Ao mesmo tempo, demonizar os denominados Botocudos fazia parte do substrato ideológico do desmonte de uma política colonial que historicamente havia garantido os direitos de vassalagem aos índios. Ainda que na prática permanecessem as diferenças entre índios e não índios, como bem lembra Lopes, ${ }^{59}$ legalmente os índios eram vassalos ou potenciais vassalos da Coroa. Demonizá-los significava, dentre outras estratégias, legitimar a perseguição e expulsão dos Botocudos dos espaços territoriais de interesse da expansão agrícola.

Para Izabel Missagia de Matos, que se debruçou sobre as práticas indigenistas empenhadas em promover a mestiçagem dos aldeados do Itambacuri, na Província de Minas Gerais, através da metodologia da catequese capuchinha observada para aquela região, "[a] exclusão do indígena 'puro' - no limite, incorrigível - fez parte da lógica colonizadora e civilizatória que pautou a catequese do Itambacuri".$^{60}$ Em outras palavras, em fins do século XIX, diferentemente dos aldeados em vias de mistura e civilização, os Botocudos da Província mineira que emperravam o processo civilizador deveriam ser extirpados. A experiência indigenista do Itambacuri de

\footnotetext{
58 Idem, ibidem.

59 LOPES, Fátima Martins. Op., cit., p. 395.

60 MATTOS, Izabel Missagia de. Op., cit., p. 401.
} 
exclusão do Botocudo, o "incorrigível", ilumina nossa argumentação acerca de um discurso de demonização dos Botocudos do sul da Província da Bahia.

Convém ressaltar que, mesmo a partir do Decreto 426, a dualidade filantropia e intolerância marcarão as discussões políticas e as práticas implementadas sobre as populações indígenas do Brasil, ambas características presentes nas ideias e práticas acerca da política indigenista do século XIX. Filantropia e intolerância existiam simultaneamente em diferentes espaços socais e políticos, pois, como observou John Monteiro, "encontrava-se filantropos no sertão, como Marlière, por exemplo, do mesmo modo que se encontrava patrocinadores de chacinas nas cidades" ${ }^{61}$ Nessa direção, bem serve de exemplo a radical posição "antiindígena" de Francisco Adolpho de Varnhagen, no quarto ponto do seu Discurso Preliminar:

\begin{abstract}
[...] Assim longe de condemnarmos que se fizesse uso da coacção pela força para civilizar os nossos Indios, estamos persuadidos que não era possível haver emprego outro meio; e que delle havemos ter que lançar mão nós mesmos, em proveito do paiz, que augmentará seus braços uteis, em favor da dignidade humana, que se vexa em presença de tanta degradaçãao ${ }^{62}$.
\end{abstract}

Ao que parece, a ideia de civilizar o índio paradoxalmente abrigava alternativas opostas. Aldear e "civilizar" eram a tônica oficial. Mas, na prática, quando essa opção se colocava difícil de realizar, a opção pela expulsão e

61 MONTEIRO, John Manuel. Op., cit., 2001, p. 142.

62 VARNHAGEN, Francisco Adolpho. "Discurso Preliminar: os índios perante a nacionalidade brazileira". In: Os Índios e a ordem Imperial. MOREIRA NETO, Carlos Araújo. Brasília: Funai, 2005 [1852], p. 326. 
perseguição se tornaram alternativas corriqueiras. Para John Monteiro, "civilizar ou exterminar, estas alternativas que remontavam aos primórdios da colonização, moviam as discussões nos sertões e nas cidades". ${ }^{63}$

A Carta Régia de 1798, que abolia o Diretório Pombalino, dentre outras medidas, decretava o fim da guerra ofensiva aos grupos indígenas resistentes ao processo de colonização dos sertões; mas, ao mesmo tempo, admitia a guerra defensiva, que terminava por significar o mesmo processo $^{64}$. Na prática, continuavam legítimos os mecanismos de violência e perseguição contra os índios denominados botocudos. Para Moreira Neto, um dos principais motivos para as decretações de "guerra justa" às populações indígenas, em início do século XIX, estava relacionado à transferência da corte portuguesa para o Brasil, em 1808, e, consequentemente, ao interesse expansionista de tornar colonizáveis os territórios historicamente pertencentes às populações resistentes a tal processo.

No bojo de reflexão acerca da transferência do poder real para o Brasil e de intensificação das ações "anti-indígenas", Cunha destaca a figura de dom João VI, cuja atuação desencadeou, a partir de1808, violentas guerras ofensivas contra os indígenas denominados botocudos, com o fim de colonizar o Vale do Rio Doce ${ }^{65}$. Vânia Moreira observou que, na Capitania do Espírito Santo, a resistência de populações indígenas, que perdurou por todo o século XIX, era o grande problema a ser enfrentado pelos "luso-brasileiros". ${ }^{66}$ Ainda destacou que, até a década de 1840, os ataques à Província do Espírito Santo,

63 MONTEIRO, John Manuel. Op., cit., 2001, p. 143.

64 MOREIRA NETO, Carlos de Araújo. Op., cit., p. 234.

65 CUNHA, Manuela Carneiro da. Op., cit., p. 136.

66 MOREIRA, Vânia Maria Losada. Op., cit., 2010b, p. 399. 
pelos Botocudos se intensificaram, o que tornou as ações governamentais contra eles ainda mais coercitivas e violentas. Nesse processo, a Carta Régia de 1808 assegurou incentivos financeiros aos militares "que evitassem mortes de portugueses e destruição de suas plantações em seus respectivos distritos e que conseguissem aprisionar e matar maior número de índios". ${ }^{67} \mathrm{~A}$ observação de Moreira demonstra a intensidade da atuação beligerante colonizadora sobre os denominados Botocudos naquela região. A mesma postura governamental aparecerá por toda parte, no Império, onde os Botocudos estivessem.

Na Bahia e em Minas, segundo Paraíso, "três Cartas Régias definiram a ação local contra os Botocudos: as de 13/5, 5/11 e 12/12 de 1808". ${ }^{68}$ Para a autora o estopim da guerra no sul da Bahia se deu pelo enfrentamento dos índios à família de Gonçalves da Costa, que atuava historicamente na ocupação territorial da região. Como apontamos anteriormente, a família de Gonçalves da Costa tinha interesses econômicos na região da Vila de Conquista e desejava manter um corredor de comércio entre a região e Minas, visto que havia implantado a pecuária na região do rio Pardo e precisava tornar transitável e seguro aquele território ${ }^{69}$.

Missagia de Mattos salienta que o etnônimo Botocudo carrega, subjacentemente, um sentido pejorativo, expresso nos relatos das experiências do colonizador com essas populações em Minas, ao longo do XIX. Contudo, a autora mantém o termo Botocudo em seu estudo de maneira metodologicamente "deformada" do sentido primeiro,

\footnotetext{
67 Idem, p. 400.

68 PARAÍSO, Maria Hilda Baqueiro. Op., cit., 1992, p. 416.

69 Idem, p.416-417
} 
como ela própria esclarece. De forma contrária ao sentido depreciativo empregado para os atores que faziam uso dos Botoques nos lábios, Mattos emprega o uso do termo Botocudo "para identificar os atores confusamente dispersos nas fontes e enfatiza a coerência de seu protagonismo no interior dos processos históricos" ${ }^{\prime 70}$. Ela frisa, ainda, que a utilização do termo Botocudo muitas vezes se apresenta mais adequado se empregado no plural, no sentido de dar visibilidade a sua pluralidade étnica.

Também em nosso estudo sobre o sul da Bahia, poucas fontes dão visibilidade aos subgrupos que estavam sob a abrangência do termo Botocudo. No conjunto da documentação, esses atores aparecem descritos enquanto "selvagens", "bárbaros" ou "gentios". À vista disso, assim como Mattos, entendemos que a utilização do termo no plural, no sentido de dar visibilidade àqueles atores homogeneamente descritos como uma massa de "feras" indóceis, demonizada no processo de avanço da colonização dos sertões do sul da Província da Bahia, se apresenta como escolha mais adequada para dar conta de sua atuação histórica naquele processo.

No período colonial, Marcelo Dias observa que havia certo alarme das autoridades e moradores da capitania de Ilhéus com relação às proporções dos relatos sobre os ataques dos Aimorés, que, por sua vez, tinham como objetivo justificar as entradas contra os mesmos ${ }^{71}$. A ideia de Juciene Ricarte Apolinário sobre os akroás da Capitania do Piauí nos anos coloniais é consonante a observação de Dias para os Aimorés da Capitania de Ilhéus. Apolinário observa que, no processo colonizador

70 MATTOS, Izabel Missagia de. Op., cit., p. 30.

71 DIAS, Marcelo Henrique. Op., cit., 2007b, p. 190. 
do sul do Piauí, no século XVIII, a construção da ideia de hostilidade dos Akroás legitimava a ação "etnocida" colonizadora. Nas palavras da autora, "Os ataques dos povos indígenas narrados nos documentos coloniais mitificavam os Akroá e constituíam um poder discursivo que justificava as ações violentas dos conquistadores". ${ }^{72}$

No século XIX, a descrição de animalidade e consequente demonização dos índios resistentes à colonização permanecerá nos relatos das correspondências entre autoridades locais e provinciais. Contudo, as intenções que guardavam as justificativas das autoridades governamentais de Ilhéus, nos idos do XIX, eram outras. No sul da Bahia, os Pataxós e Botocudos figuravam nos registros documentais como os entraves ao sucesso colonizador. Nota-se isso nas narrativas sobre os ataques dos Pataxós e Botocudos ao Aldeamento de Ferradas, à estrada, aos colonos e às fazendas. Em todos os documentos em que aparecem essas narrativas, via de regra aparece também a solicitação de armas, munição, ferramentas e verbas aos cofres provinciais. Nesse sentido, diferentemente da realidade observada para o período anterior, estudado por Dias e Apolinário, nos anos imperiais a estratégia central não era apenas legitimar entradas contra as populações resistentes à colonização, pois visava-se, igualmente, conseguir, do governo central da Bahia, benesses materiais e econômicas.

Concernente à ideia de demonização dos Botocudos por parte das autoridades da Vila de Ilhéus, bem como

72 APOLINÁRIO, Juciene Ricarte. “Os Akroá nos sertões coloniais: uma história de guerra e 'paz' entre currais e descobertos auríferos". In: OLIVEIRA, João Pacheco de (Org.). A presença indígena no Nordeste: processos de territorialização, modos de reconhecimento e regimes de memória. Rio de Janeiro: Contra capa, 2011, p. 150. 
pelos missionários capuchinhos que atuavam nos aldeamentos do sul da Bahia, destacamos o conteúdo de um requerimento de Frei Ludovico ao juiz de paz da vila de Ilhéus, datado de 13 de julho de 1840.

Frei Ludovico requeria do juiz da Vila de Ilhéus providências militares contra os Botocudos diante de um caso de "assassinato" de um dos aldeados, que o frade afirmava ter sido cometido por eles. O relato sugeria uma cena de horror e demonstrava que o crime havia sido cometido com requintes de barbaridade. Na sequência, o frade descrevia a realidade de medo em que, segundo ele, se encontravam os aldeados de Ferradas:

[...] Na mesma hora pouco antes do meio dia os seis homens que forão, trouxerão o corpo a esta Povoação, que toda ficou em susto, e terror [...]. Todos estes Indios assustados por se verem expostos a huma nova traição de hum inimigo escondido se refugiarão nas suas cazas, vigiando de dia e de noite, por explorar o numero, a qualidade e o intento dos agressores, em lugar como este descampado. ${ }^{73}$

O relato de Ludovico demonstra o caráter de demonização dos Botocudos, descritos frequentemente como seres desumanos, hostis e ferozes. No relato daquele episódio, Frei Ludovico destaca que pela maneira de fabricação das flechas se sabia que os bárbaros eram botocudos, e menciona que muito provavelmente aqueles botocudos estavam ali "tangidos, e enfurecidos da peleja de Mucuri e Rio Do$\mathrm{ce}^{\prime \prime 74}$. Nesse contexto, retomamos a realidade beligerante na

73 APEB; Seção Colonial e Provincial; Série Judiciário; maço 2395-1; ano 1840.

74 Idem 
qual se encontravam os índios das vizinhas Províncias de Minas e do Espírito Santo; como já mencionado, maiores medidas militares contra os Botocudos do Espírito Santo foram implementadas dentre 1800 e $1840^{75}$. Desse modo, era provável, portanto, que os denominados Botocudos migrassem para o sul da Bahia, fugidos ou expulsos dos seus territórios no rio Doce. Maria Rosário de Carvalho, em estudo sobre os índios da Vila do Prado, extremo sul da Bahia, menciona a migração dos indígenas afugentados dos arredores de Minas para o extremo sul baiano, e diz que sua simples presença na região era motivo de interpelação violenta e beligerante ${ }^{76}$.

No relato sobre o ataque à roça e sobre a morte do aldeado José Antonio, o frade ressalta a certeza de que os "bárbaros" eram os "Botocudos". Acrescentava que, certamente, não eram os "Patachós tanto pelo feitio das flechas, como pela certeza de que em vinte e quatro annos com suas frequentes chegadas nunca estes fizerão mal"77. Ludovico conclui o seu relato sobre o episódio ocorrido em São Pedro de Alcântara, solicitando ao juiz de paz da vila de Ilhéus, que fossem tomadas as devidas providência: "que seja servido nos limites de sua jurisdição expedir só sem demora huma força provisória, se não offensiva, pelo menos deffensiva". ${ }^{78}$

A solicitação de Ludovico de Livorno de medidas ofensivas ou defensivas contra os Botocudos que ameaçavam

75 MOREIRA, Vânia Maria Losada. Op., cit, 2010b, p. 400.

76 CARVALHO, Maria Rosário de. "Indios do sul e extremo sul baianos: reprodução demográfica e relações interétnicas". In: OLIVEIRA, João Pacheco de (Org.). A presença indígena no Nordeste: processos de territorialização, modos de reconhecimento e regimes de memória. Rio de Janeiro: Contra Capa, 2011, p. 367.

77 APEB; Seção Colonial e Provincial; Série Judiciário; maço 2395-I; ano 1840. 78 Idem. 
Ferradas corrobora as práticas vigentes em nível nacional e demonstra o mecanismo de perseguição às populações indígenas do sul da Bahia. Como bem observou John Monteiro, "atrair ou repelir, civilizar ou exterminar [...]. A noção de civilização, ao que parece, abrigava os dois extremos" ${ }^{\prime 79}{ }^{\text {É conso- }}$ nante com essa observação de Monteiro a fala do alferes comandante do quartel da Cachoeirinha, José Atanásio Ribeiro, a um juiz da Vila de Ilhéus: "Ill.m Snr. não há outro algum remédio mais do que a força das marchas sobre esses ferozes sedentos do sangue humano". 80

Em correspondência ao presidente da província, em 25 de abril de 1842, o juiz municipal interino da vila de Ilhéus, Antônio Lopes Benevides, relata ao governo provincial um conflito entre Botocudos e Camacãs do Aldeamento de Ferradas, quando os Botocudos foram feridos, afugentados e quatro morreram na referida contenda. $\mathrm{O}$ juiz se reporta ao governo provincial preocupado com um possível ataque de vingança dos botocudos:

(...) Este acontecimento, que teve logar no dia 16 do corrente promete as mais serias consequências, pois que não havendo aquelles selvagens recebido já mais a menor vendicta dos Camacans, apezar de insolente e barbaramente provocados não cessavão de repetir as suas depredações, agora estimulados por certo procurarão vingar-se em occazião opportuna da perda que soffrerão, e accometerial raivozamente essa indefeza Povoação se promptamente lhe não fosse mandado socorro; o qual tendo-me sido requizitado pelo mencionado Pe. Missionário Fr. Ludovico que teme seja perdido o fructo

79 MONTEIRO, John Manuel. Op., cit., 2001, p. 143.

80 APEB; Seção Colonial e Provincial; Série Judiciário; maço 2396; ano 1840. 
de seos trabalhos apostólicos com aniquilação de hua tão interessante Povoação ${ }^{81}$.

Muito embora os Botocudos estivessem em situação de desvantagem diante dos Camacãs, que estavam munidos de armas de fogo, belicamente mais poderosas que as flechas dos Botocudos, o relato do juiz municipal faz ecoar certo alarme na descrição das consequências a que a população estaria submetida, caso não se garantisse a ela o socorro do governo central da Bahia.

O seu relato guardava um tom de comoção; e parece interessar-se, o presidente provincial, em garantir a requisição feita na sequência:

Tomei por tanto a deliberação d'accordo com o respectivo juiz de Paz e o Tenente Coronel da G. N. de enviar para ali hum destacamento de 16 G. 2 Cabos e huma corneta commandados por hum Sargento [...]. He o destacamento composto de gente pobre que por isso não quis prestar-se a esta deligencia sem a solene promessa de serem abonados soldos equivalentes as privações que vão soffrer os auzentes de suas formas que sustentão com seo trabalho mecânico, e rural, ou separados dos commodos da vida social a se exporem nas matas as flexas dos selvagens ${ }^{82}$.

Portanto, Benevides comunica ao governo provincial a decisão de enviar para o aldeamento reforço militar para combater os Botocudos num suposto ataque de vingança. Para tanto, o juiz municipal conclui a correspondência requerendo verba para o sustento dos homens destinados

81 APEB; Seção Colonial e Provincial; Série Judiciário; maço 2395-I; ano 1842.

82 APEB; Seção Colonial e Provincial; Série Judiciário; maço 2395-I; ano $1842 .$. 
para manter a segurança de Ferradas. Ao final do documento, Benevides argumenta que, pela urgência do caso, ele havia conseguido empréstimos de dinheiro, armas e munição de cidadãos locais e solicita ao governo provincial que aprovasse suas decisões. De forma implícita, solicitava, ao presidente da Província, ressarcimento da verba. Deixa em evidência "que [garantia o empréstimo] em nome de Vossa Excelência" ${ }^{13}$. Ele justificava as medidas tomadas, pois desejava a manutenção da segurança da povoação de São Pedro de Alcântara, bem como da vila de Ilhéus contra os ataques dos Botocudos.

Em 24 de novembro de 1840, Jerônimo dos Santos Quaresma, juiz municipal de Ilhéus, dirigiu-se ao presidente da Província informando acerca de outro ataque dos Botocudos ao Aldeamento de Ferradas. Aventa a possibilidade levantada por Frei Ludovico, de substituir a solicitação feita ao governo provincial de reforço militar para o aldeamento, pela disponibilização de armas e munições. Jerônimo Quaresma justifica que,

(...) por ser aquella ditta Povoação cituada no meio de uma imença matta, a margem do Rio Caxoeira, que há de distar desta Villa, pelo menos oito a nove legoas, em cujas mattas, essas praças que o Exmo. Governo ordenou ali destacarem, nenhum conhecimento della podem ter, e por isso se deve aprovar o plano dado pelo Religioso Vigário em seo Officio, de serem providos aquelles Povoadores, com armamento, e suficientemente munidos de pólvora, e chumbo groço, visto haver na Povoação gente suficiente de defender-se, logo que sejão armados, se V. Exa. ouver, por bem assim o determinar,

83 APEB; Seção Colonial e Provincial; Série Judiciário; maço 2395-I; ano 1842. 
e servir-se mandar suspender a ordem de vir o destacamento; ficará a Povoação mais defendida, e será para a Thesouraria menos dispendiozo, do que o suprimento do ditto destacamento ${ }^{84}$.

O documento se inicia relatando a morte do aldeado José Vitório e o estado de pavor da população de Ferradas perante os ataques dos botocudos. Diante do exposto, seria mais razoável optar pela disponibilização do imediato reforço militar. Contudo, o frade revoga a solicitação anterior e envia outro ofício solicitando armas e munição, postura bem contraditória em face da urgência que, segundo ele, pedia a situação. Ludovico pede a revogação de uma solicitação já liberada pelo governo central, para pedir armamento e munição, uma nova solicitação, que demandaria mais tempo para a sua disponibilização.

No último relato selecionado, os indígenas classificados como "selvagens" eram os pataxós. A correspondência contendo o relato do missionário Vicente Maria de Ascoli, então diretor de São Pedro de Alcântara, foi enviada pelo diretor geral dos índios ao presidente da província, Alvaro Tibeiro de Moncorvo, no dia 10 de dezembro de 1855:

O missionário director da aldeia de S. Pedro de Alcantara, do termo dos Ilheos Fr Vicente M. ${ }^{a}$ d'Ascoles participa-me em data de 3 do corrente que os selvagens Pataxós tem atacado sua aldeia de Camacans desde junho (...) de sorte q. já tem avido conflitos de q. sahirão feridos dos Camacans, sem saber o [il.] missionário o que aconteceo aos selvagens. Informa q. entre o rio Salgado e a

84 APEB; Seção Colonial e Provincial; Série Judiciário; maço 2395-I; ano 1840. 
[Estiva] na estrada da conquista achou-se a mão de 1 homem cortada, o q. elle atribui ser dos Pataxós. Pede providencias, e ora não me ocorra outra se não authorisar V. Ex. ${ }^{a}$ pelo cofre geral e verba de estradas a abertura da de Ilheos para Minas a cargo do dous missionários Fr Vicente $\mathrm{M}^{\mathrm{a}}{ }^{\mathrm{d}} \mathrm{d}^{\prime}$ Ascoles e Fr. Rainero de Ovada, a fim de attrahir [moradas] q. afugentem os índios bravos em quanto não podem ser allienados pelos missionários ${ }^{85}$.

No fragmento acima citado, o conflito entre camacãs aldeados e os Pataxós que habitavam aquelas redondezas foi utilizado como argumento para a solicitação de verba existente nos cofres provinciais, destinadas às obras da estrada. $\mathrm{O}$ relato desse conflito, assim como o dos demais, valoriza o medo e a desordem para, ao que tudo indica, persuadir as autoridades provinciais. Ao supervalorizarem as situações de violência e ao demonizarem os Pataxós e os Botocudos, tratam os conflitos como artifício para solicitar recursos materiais e financeiros ao governo provincial.

Marcelo Henrique Dias observa, em seus estudos sobre a Capitania de Ilhéus, a construção do "mito da devastação da Capitania pelos aimorés". Dias ressalta que a historiografia regional reduziu as populações indígenas ao papel de entraves ao bom êxito da colonização, responsabilizando-as pela decadência de Ilhéus no século XIX ${ }^{86}$, e frisa que "uma investigação mais atenta nos testemunhos de época revela um certo grau de alarmismo nos discursos de então, os quais, muitas vezes, não correspondiam à real

85 APEB; Seção Colonial e Provincial; Série Agricultura; maço 4613; ano 1855.

86 DIAS, Marcelo Henrique. Op., cit., 2007b, p. 188-189. 
dimensão das ocorrências [que] (...), normalmente antecediam a organização de entradas" ${ }^{\prime 77}$.

O mesmo tom de alarmismo observado por Dias reaparece em relação aos Pataxós e aos Botocudos, durante o século XIX, nos registros das autoridades governamentais e dos missionários da então Comarca de Ilhéus. Parecia imperioso e interessante, para o governo local, construir uma imagem demonizada dos Botocudos, e da região como estando continuamente atacada por seres que beiravam a animalidade. Essa estratégia visava claramente dois objetivos: legitimar a perseguição, a expulsão e até mesmo o extermínio dos grupos indígenas que não aceitavam a vivência nos aldeamentos; e alimentar a imagem de fereza dos botocudos e Pataxós, para obter o apoio financeiro do governo provincial.

87 Idem, p. 190. 